\title{
Effect of Cell Cycle Inhibition on Cisplatin-Induced Cytotoxicity*
}

Melissa L. Fishel, David R. Newell, Roger J. Griffin, Richard Davison, Lan-Zhen Wang,

Nicola J. Curtin, Eleanor G. Zuhowski, Kristen Kasza, Merrill J. Egorin, Robert C. Moschel, and M. Eileen Dolan

Department of Medicine, Committee on Cancer Biology and Cancer Research Center

[M.L.F., M.E.D.], Department of Health Studies, [K.K.], University of Chicago, Chicago,

IL 60637; Northern Institute for Cancer Research, University of Newcastle, Newcastle

upon Tyne, UK [D.R.N., R.J.G., R.D., L-Z.W., N.J.C.]; University of Pittsburgh Cancer

Institute, Pittsburgh, PA 15213 [E.G.Z., M.J.E.]; Laboratory of Comparative

Carcinogenesis, National Cancer Institute at Frederick, Frederick, MD 21702-

1201[R.C.M] 
Running Title: Use of guanine derivatives to enhance cisplatin cytotoxicity

Corresponding author: M. Eileen Dolan University of Chicago, 5841 S. Maryland Ave., Box

MC2115, Chicago, IL 60637. Phone: (773) 702-4441; Fax: (773) 702-0963; E-mail:

edolan@medicine.bsd.uchicago.edu

Number of text pages: 28

Number of tables: 1

Number of figures: 7

Number of references: 42

Number of words in Abstract: 177

Number of words in Introduction: 602

Number of words in Discussion: 886

Abbreviations used are: $\mathrm{CDK}$, cyclin-dependent kinase; $O^{6}$-BG, $O^{6}$-benzylguanine; $S^{6}$-BG, $S^{6}$ benzyl-6-thioguanine; $S^{6}$-CMG, $S^{6}$-cyclohexylmethyl-6-thioguanine; $O^{6}$-CMG, $O^{6}$ -

[(cyclohexyl)methyl]guanine; 9- $\mathrm{CH}_{3}-\mathrm{BG}, O^{6}$-benzyl-9-methylguanine; 9- $\mathrm{CH}_{3}-\mathrm{CMG}, O^{6}$ -

[(cyclohexyl)methyl] -9-methylguanine; N7-BG, 7-benzylguanine; TSA, Trichostatin A; SAHA, suberoylanilide hydroxamic acid.

Chemotherapy, Antibiotic, \& Gene Therapy 


\section{ABSTRACT}

Pharmacological inhibitors of CDK2 are currently in preclinical and clinical development. The purpose of our work was to evaluate a series of guanine derivatives for their ability to inhibit CDK2, affect cell cycle progression, and enhance the cytotoxic and apoptotic effects of cisplatin. A panel of guanine derivatives including $O^{6}$-benzylguanine $\left(O^{6}\right.$-BG), $S^{6}$-benzyl6-thioguanine ( $S^{6}$-BG), $S^{6}$-cyclohexylmethyl-6-thioguanine $\left(S^{6}-\mathrm{CMG}\right), O^{6}$ [(cyclohexyl)methyl]guanine $\left(O^{6}-\mathrm{CMG}\right), O^{6}$-benzyl-9-methylguanine $\left(9-\mathrm{CH}_{3}-\mathrm{BG}\right), O^{6}$ [(cyclohexyl)methyl] -9-methylguanine (9- $\left.\mathrm{CH}_{3}-\mathrm{CMG}\right)$, 7-benzylguanine (N7-BG) exhibited varying degrees of CDK2 inhibition with $O^{6}-\mathrm{CMG}$ being the most potent and 9- $\mathrm{CH}_{3}-\mathrm{BG}$, 9$\mathrm{CH}_{3}-\mathrm{CMG}$, and N7-BG the least potent compounds. Treatment with $S^{6}-\mathrm{CMG}$ and $O^{6}-\mathrm{CMG}$ significantly decreased the percentage of cells in S phase. In SQ20b and SCC61 head and neck cancer cell lines, the most potent $\mathrm{CDK} 2$ inhibitor, $O^{6}-\mathrm{CMG}$, was also the most effective at enhancing cisplatin-induced cytotoxicity and apoptosis. Cisplatin-induced DNA platination increased in SQ20b cells pretreated with $S^{6}-\mathrm{BG}, S^{6}-\mathrm{CMG}$, and $O^{6}-\mathrm{CMG}$. Treatment with both $O^{6}$-BG and trichostatin A (TSA), an indirect cell cycle inhibitor, demonstrated additive effects on cisplatin-induced cytotoxicity. In summary, we have identified a group of guanine derivatives that were effective modulators of cisplatin-induced cytotoxicity and apoptosis. 
Combinations of conventional anti-cancer drugs with direct and indirect cell cycle inhibitors are currently being investigated clinically to determine if combining these inhibitors with cytotoxic chemotherapeutic agents will improve clinical response. The tightly controlled regulation of cell cycle progression involving cyclin dependent kinases (CDKs) ${ }^{3}$ and their cyclin partners is disrupted in neoplastic cells compared to non-neoplastic tissues, thereby making this a target for anti-cancer therapies (Ruetz et al., 2003). Compounds that have a direct effect on cell cycle and that have entered clinical trials include flavopiridol, CTC-202, BMS-387032, and UCN-01. In addition to inhibiting cell cycle CDKs, these agents exhibit activities against other kinases that may reduce anti-tumor selectivity and result in toxicity that is not related to cell cycle inhibition (Bertrand et al., 1994; Carlson et al., 1996; Parker et al., 1998; Toogood, 2001). For example, UCN-01, although developed as a protein kinase C inhibitor (Mizuno et al., 1995), exerts effects on cell cycle via inhibition of CDKs (Akiyama et al., 1997) and abrogation of the DNA damage checkpoints (reviewed in (Senderowicz, 2003a).Unfortunately, flavopiridol and UCN-01 have demonstrated minimal activity as single agents in Phase I/II studies (reviewed in (Sausville et al., 2001; Grant and Roberts, 2003). Likewise, combinations of flavopiridol with conventional chemotherapy including paclitaxel, cisplatin, and irinotecan has not produced striking results (Grant and Roberts, 2003).

Cyclin D antagonists, p27 inducers, and differentiation-inducing agents such as all trans-retinoic acid, phorbol myristate acetate, and histone deacetylase inhibitors, i.e. trichostatin A and sodium butyrate, are all examples of indirect cell cycle inhibitors (Grant and Roberts, 2003). An indirect cell cycle inhibitor exerts its effects on targets upstream of the cell cycle rather than on the CDK enzymes themselves (Senderowicz, 2003b). Both direct 
and indirect cell cycle inhibitors have been able to potentiate the effects of cytotoxic agents including mitomycin $\mathrm{C}$, cisplatin, radiation, gemcitabine and ara-C in vitro (reviewed in (Grant and Roberts, 2003; Kim et al., 2003; Senderowicz, 2003b), however improved therapies are needed in this area.

To overcome the limitations of first generation CDK inhibitors, tremendous effort, often supported by structural biology, has gone into discovering potent, more selective CDK inhibitors (Knockaert et al., 2002). Targets include CDK2/cyclin E and CDK2/cyclin A because they play a central role in driving the cells from G1 into S phase, and through $\mathrm{S}$ phase progression, respectively (Vermeulen et al., 2003). One such compound is $O^{6}$-CMG which is more specific for CDK1/2 than are other purine-derived compounds and has a differential pattern of tumor cell growth inhibition when compared with flavopiridol and olomoucine, the predecessor of CYC-202 (Schulze-Gahmen et al., 1995; De Azevedo et al., 1997; Arris et al., 2000). Important interactions between $O^{6}-\mathrm{CMG}$ and CDK2 include a triplet of hydrogen bonds (i.e., purine NH-9 to Glu 81, purine N-3 to Leu 83, and purine 2$\mathrm{NH}_{2}$ to Leu 83) and the cyclohexyl ring of $O^{6}-\mathrm{CMG}$, that confers specificity for CDK 1 and 2 over CDK4 (Arris et al., 2000; Davies et al., 2002).

Here, we evaluate a series of guanine-derived compounds related to $O^{6}$-CMG including $O^{6}$-BG, $S^{6}-\mathrm{BG}, S^{6}-\mathrm{CMG}, 9-\mathrm{CH}_{3}-\mathrm{BG}, 9-\mathrm{CH}_{3}-\mathrm{CMG}$ and N7-BG (Figure 1), for their ability to directly inhibit CDK2 and inhibit cell cycle progression. Using these guanine derivatives, we compared the extent of CDK2 inhibition with the degree of enhancement of cisplatin-induced cytotoxicity and apoptosis to test the hypothesis that cell cycle perturbation by CDK inhibition results in enhancement of cisplatin cytotoxicity. Furthermore, we measured the degree of DNA platination following cisplatin treatment in the presence and 
absence of these guanine derivatives. We also evaluated whether TSA, an indirect cell cycle inhibitor, could further enhance cisplatin-induced cytotoxicity when combined with guanine derivatives.

\section{Materials and Methods}

Cell lines. The head and neck cancer cell lines, SQ20b and SCC61 were kindly provided by Dr. Michael Beckett (Department of Radiation and Cellular Oncology, University of Chicago). These cell lines were maintained at $37^{\circ} \mathrm{C}$ and $5 \% \mathrm{CO}_{2}$ in Dulbecco's MEM/F12 (50/50 mixture, Mediatech, Inc., Herndon, VA) supplemented with 20\% fetal bovine serum (Hyclone, Logan, UT), $0.4 \mu \mathrm{g} / \mathrm{ml}$ hydrocortisone (BD Biosciences, Bedford, MA), and 1\% penicillin/ streptomycin (Mediatech, Inc., Herndon, VA).

Materials. Cisplatin and TSA were purchased from Sigma Aldrich (St. Louis, MO). $O^{6}$-BG, $S^{6}$-BG, N7-BG, and 9- $\mathrm{CH}_{3}-\mathrm{BG}$ were synthesized as described previously (Dolan et al., 1990; Moschel et al., 1992; Chae et al., 1994).

$S^{6}$-CMG was synthesized from 6-thioguanine (Aldrich Chemical Co., Milwaukee, WI). UV spectra were determined on a Beckman Coulter DU 7400 spectrophotometer. ${ }^{1} \mathrm{H}-$

NMR spectra were recorded in DMSO- $\mathrm{d}_{6}$ with a Varian INOVA $400 \mathrm{MHz}$ spectrometer.

Chemical shifts are reported as $\delta$ values in parts per million relative to tetramethylsilane

(TMS) as internal standard. Mass spectra were obtained on a Thermo Finnigan TSQ

Quantum mass spectrometer. To a solution of $2 \mathrm{~g}$ of 6-thioguanine $(0.012 \mathrm{~mol})$ dissolved in $75 \mathrm{~mL}$ of $\mathrm{MeOH} / \mathrm{H}_{2} \mathrm{O}(1: 1)$ containing $12 \mathrm{~mL}$ of $2 \mathrm{~N} \mathrm{NaOH}$ was added $1.6 \mathrm{~mL}$ of bromomethylcyclohexane $(0.011 \mathrm{~mol})$, and the suspension was stirred vigorously for 9 days at room temperature. The resulting homogeneous solution was treated with $1.4 \mathrm{~mL}$ glacial 
acetic acid, and the precipitated solid was filtered. The recovered solid was suspended with stirring in $170 \mathrm{~mL}$ of $\mathrm{EtOH} / \mathrm{H}_{2} \mathrm{O}(1: 1)$ which was brought to boiling. The solution was gravity filtered hot to remove a fine yellow precipitate. The filtrate was allowed to cool slowly to room temperature. After 48 hours, additional fine yellow precipitate was deposited, and this was also filtered. EtOH was allowed to slowly evaporate spontaneously which caused a white crystalline solid to precipitate. This was suction filtered (0.36 g). EtOH was evaporated under vacuum which caused precipitation of additional white precipitate. The pooled white solid was crystallized from $100 \mathrm{~mL}$ of acetone/ $\mathrm{H}_{2} \mathrm{O}$ to afford $1.5 \mathrm{~g}$ of $S^{6}$-CMG. $\mathrm{UV}\left(\mathrm{H}_{2} \mathrm{O}\right) \lambda_{\max } 244,256(\mathrm{sh}), 312 ;{ }^{1} \mathrm{H}-\mathrm{NMR}$ (DMSO-d 6 /TMS) $\delta 12.47$ (br s, $1 \mathrm{H}, \mathrm{NH}$, exchanges with $\left.\mathrm{D}_{2} \mathrm{O}\right), 7.88$ (s, $\left.1 \mathrm{H}, \mathrm{H}-8\right), 6.27$ (s, $2 \mathrm{H}, \mathrm{N}^{2} \mathbf{H}_{2}$, exchange with $\left.\mathrm{D}_{2} \mathrm{O}\right), 3.20$ (d, J $\left.=6.8 \mathrm{~Hz}, 2 \mathrm{H}, \mathrm{SCH}_{2}\right), 1.90-0.97\left(\mathrm{~m}, 11 \mathrm{H}, \mathrm{C}_{6} \mathbf{H}_{11}\right)$; MS Calcd. m/z for $\mathrm{C}_{12} \mathrm{H}_{17} \mathrm{~N}_{5} \mathrm{~S}: 263.1205$; Found: 263.1208 .

$O^{6}$-CMG (also known as NU2058) and 9- $\mathrm{CH}_{3}-\mathrm{CMG}$ (also known as NU6052) were synthesized as previously described (Arris et al., 1994; Lembicz et al., 1997).

CDK2 Inhibition Assay. Inhibition of CDK2/CyclinA3 was assayed as previously described (Arris et al., 2000). The final ATP concentration in the CDK assay was $12.5 \mu \mathrm{M}$, and the $\mathrm{IC}_{50}$ concentration for each compound is the concentration required to inhibit enzyme activity by $50 \%$ under the assay conditions used. The assay buffer was comprised of $50 \mathrm{mM}$ Tris$\mathrm{HCl}$, pH7.5 containing $5 \mathrm{mM} \mathrm{MgCl}_{2}$.

Cell cycle staining analysis. To stain the cells for DNA content and analyze the percentage of cells in G0/G1, S, and G2/M, approximately $1.4 \times 10^{6}$ cells were plated in a T75 flask and 
allowed to attach overnight. After pretreatment with guanine derivative $(10 \mu \mathrm{M})$ for $2 \mathrm{~h}$, cisplatin was added for 2 h. Cells were washed twice with PBS after drug treatment, and normal growth medium returned to the flask. Cells were harvested $16 \mathrm{~h}$ after drug treatment and washed once with PBS. Cells were then fixed in $70 \%$ ice-cold EtOH and stored at $4{ }^{\circ} \mathrm{C}$ until PI staining. To stain with PI, cells were sedimented by centrifugation, washed in PBS, and RNase was added $(0.1 \mathrm{mg} / \mathrm{mL})$. Cells were incubated at $37^{\circ} \mathrm{C}$ for $30 \mathrm{~min}$ in the RNase solution, sedimented by centrifugation, and washed in PBS to remove RNase. Cells were then resuspended in PI stain solution $(0.1 \mathrm{mg} / \mathrm{mL})$ at a final cell concentration $1 \times 10^{6}$ cell $/ \mathrm{mL}$ and were incubated on ice for 30 min prior to analysis by flow cytometry.

Colony Formation Assay. To evaluate cell survival after drug treatment, a colony formation assay was used as previously described (Fishel et al., 2003). Briefly, exponentially growing cells were exposed to guanine derivative at concentrations indicated for $2 \mathrm{~h}$ prior to the addition of up to $50 \mu \mathrm{M}$ cisplatin. Following incubation with guanine derivative and cisplatin at $37^{\circ} \mathrm{C}$, the cells were replated in triplicate at varying densities between 150 and 3000 cells per 100-mm dish. After approximately 12 days, colonies were stained with methylene blue $(0.1 \% \mathrm{w} / \mathrm{v})$ and scored. Percentage survival was calculated based on the plating efficiency of the appropriate set of control cells exposed to vehicle alone. In experiments with TSA (25 $\mathrm{ng} / \mathrm{mL})$, exponentially growing cells were treated for $24 \mathrm{~h}$ prior to addition of $O^{6}-\mathrm{BG}(2 \mathrm{~h}$ pretreatment and $2 \mathrm{~h}$ during cisplatin) or cisplatin $(2 \mathrm{~h})$.

Determination of Apoptotic Cells. To analyze cells for apoptosis, Annexin-V-FITC antibody and PI were added to the cells according to the manufacturer's indicated protocol (BD 
Biosciences Clontech, Palo Alto, CA). Samples were analyzed by flow cytometry using FACS DiVa (Becton Dickinson, San Jose, CA). As described previously, cells that were Annexin-V-FITC-positive and PI-negative were considered positive for apoptosis (Fishel et al., 2003). For Figure 3, apoptosis was analyzed using the Alexa Fluor ${ }^{\circledR} 488$ Annexin-V from Vybrant ${ }^{\circledR}$ Apoptosis Assay Kit in combination with MitoTracker® Red CMXRos, a dye that is retained in active mitochondria (Molecular Probes, Eugene, OR). To distinguish the cells with permeable membranes, DAPI (4',6-diamidino-2-phenylindole dihydrochloride) was used, and cells that were DAPI-positive were not included in the analysis for apoptosis. Samples were analyzed by flow cytometry using FACS DiVa (Becton Dickinson, San Jose, CA). The following controls were used: unstained cells, cells stained with Alexa Fluor® 488 Annexin-V only, cells stained with MitoTracker® Red, and cells stained with DAPI only. FloJo FACS analysis software (Tree Star, Inc. Ashland, OR) was used to determine cells that were Annexin-V-FITC-positive, MitoTracker Red-negative, and DAPI-negative (positive for apoptosis).

Measurement of total platinum in DNA. Atomic absorption spectroscopy was used to quantitate total platinum on DNA as described previously (Fishel et al., 2003). Exponentially growing cells were treated with modulator or vehicle for $2 \mathrm{~h}$ and then with $50 \mu \mathrm{M}$ cisplatin for an additional $2 \mathrm{~h}$. Cells were collected at 0,24 , or $48 \mathrm{~h}$ after completion of cisplatin treatment. Total genomic DNA was isolated by phenol/chloroform/isoamyl alcohol extraction and ethanol precipitation. Platinum concentration was assessed with a PerkinElmer model 1100 flameless atomic absorption spectrometer (Perkin-Elmer, Norwalk, 
Conn.) monitoring $265.9 \mathrm{~nm}$. Platinum concentrations were determined by comparison with a standard curve performed on the same day as the assay (Erkmen et al., 1995).

Statistical Analysis. Statistics for the apoptosis experiments were analyzed using analysis of variance (ANOVA) models with cisplatin dose $(0,10$, and $20 \mu \mathrm{M})$ and treatment (cisplatin alone, and cisplatin plus $O^{6}-\mathrm{BG}, S^{6}-\mathrm{CMG}, S^{6}-\mathrm{BG}$, and $\left.O^{6}-\mathrm{CMG}\right)$. In experiments with $O^{6}$-BG and TSA treatment, ANOVA models were used to test for an overall effect of cisplatin dose, treatment (none, $O^{6}$-BG, TSA, and $O^{6}$-BG plus TSA), and the interaction between cisplatin dose and treatment. The outcome employed in the statistical model was the natural logarithm of the proportion of cells surviving. If a statistically significant interaction or main effect of treatment was found using the ANOVA model (i.e. the p-value<0.05), then pairwise comparisons were made between treatment groups to determine which treatments differed. In addition, two-way ANOVA models were used to examine the interaction between $O^{6}$-BG and TSA. A separate model was fit for each of the four cisplatin doses $(0,6,12.5$, and $25 \mu \mathrm{M})$. A significant interaction would provide evidence for a synergy between the two treatment modalities.

In the DNA platination experiments, the ANOVA model was fitted to the platinum concentrations to test for an overall effect of time $(0,24$, and 48 hours post treatment), and treatment, and the interaction between time and treatment. The outcome employed in the statistical model was the square root of the platination levels due to non-normality. Of primary interest were the comparisons between samples treated with cisplatin alone to the samples treated with guanine derivatives plus cisplatin. 


\section{RESULTS}

In vitro kinase assays of the guanine derivatives. Figure 1 illustrates the structures of the guanine derivatives used in these studies. We determined the $\mathrm{IC}_{50}$ for $\mathrm{CDK} 2 / \mathrm{Cyclin} \mathrm{A} 3$ of several guanine derivatives. CDK2 was inhibited to varying degrees with the greatest inhibition by $O^{6}$-CMG and the least potent compounds those with a substituent at the 9-position $\left(9-\mathrm{CH}_{3}-\mathrm{BG}, 9-\mathrm{CH}_{3}-\mathrm{CMG}\right)$ or at the 7-position (N7-BG), (Table 1) as expected from the crystal structure (Davies et al., 2002).

Cisplatin sensitivity of SQ20b after treatment with guanine derivatives. To determine the relationship between potency of CDK2 inhibition and enhancement of cisplatin cytotoxicity, we evaluated the effect of the four most potent derivatives on cisplatin-induced cytotoxicity (Figure 2). In SQ20b cells, cisplatin cytotoxicity $\left(\mathrm{ED}_{50}\right)$ was enhanced to varying degrees by the guanine derivatives at $10 \mu \mathrm{M}$ : $S^{6}$-BG (1.6-fold), $O^{6}$-BG (1.7-fold), $S^{6}$-CMG (1.5-fold), and $O^{6}$-CMG (2.6fold) and at $100 \mu \mathrm{M}$ : $S^{6}$-BG (2.3-fold), $O^{6}$-BG (1.5-fold), $S^{6}$-CMG (3-fold), and $O^{6}$-CMG (3.3fold) (Figure $2 \mathrm{~A}, \mathrm{~B}$ ). There was a significant increase in the percentage of SQ20b cells undergoing apoptosis when cisplatin was used in combination with $10 \mu \mathrm{M} S^{6}$-CMG (1.4-fold), and $O^{6}$-CMG (1.5-fold), but not with $O^{6}$-BG (1.2-fold) or $S^{6}$-BG (Figure 2C). In the apoptosis experiment, ANOVA detected a significant main effect of treatment between cisplatin dose and treatment group $(\mathrm{p}=0.003)$. The most potent $\mathrm{CDK} 2$ inhibitor resulted in the greatest degree of enhancement in cisplatin-induced cytotoxicity and apoptosis (Table 1 and Figure 2).

Effect of poor CDK2 inhibitors on cisplatin-induced cytotoxicity. To determine whether CDK inhibition was critical for enhancement of cisplatin-induced cytotoxicity, we utilized three 
guanine derivatives that required $>100 \mu \mathrm{M}$ concentrations to inhibit $\mathrm{CDK} 2$ in vitro. $9-\mathrm{CH}_{3}-\mathrm{BG}$ and 9- $\mathrm{CH}_{3}-\mathrm{CMG}$ were designed with a methyl group at the $\mathrm{N}-9$ position to disrupt the $\mathrm{H}$-bonds which are thought to be critical for CDK2 inhibition (Arris et al., 2000). As shown in Figure 3, the $\mathrm{ED}_{50}$ of cisplatin was enhanced 1.6-fold with 9- $\mathrm{CH}_{3}-\mathrm{CMG}$ and was not enhanced by $9-\mathrm{CH}_{3}-$ BG (1.1-fold) or N7-BG (1.0-fold) at $50 \mu \mathrm{M}$ nor did they result in increased apoptosis (Figure 3, inset), consistent with the hypothesis that CDK2 inhibition is coincident with potentiation of cisplatin-induced cytotoxicity. The dose of $50 \mu \mathrm{M}$ guanine derivative was chosen in these experiments due to limited solubility of some of these compounds.

Cisplatin sensitivity of SCC61 after treatment with guanine derivatives. To extend our results observed in SQ20b head and neck cancer cell lines, experiments were performed in SCC61, another head and neck cancer cell line. Similar to SQ20b cells, $O^{6}$-CMG and $S^{6}$-BG were the most and least effective modulators of cisplatin-induced cytotoxicity, respectively (Figure 4A, B). ANOVA demonstrated a significant interaction between treatment and cisplatin dose for these cell survival experiments $(\mathrm{p}<0.001)$. The observed increase in cytotoxicity with the modulators correlated well with an increase in the percentage of SCC61 cells undergoing apoptosis when exposed to $20 \mu \mathrm{M}$ cisplatin [ $S^{6}$-BG (1.5-fold), $O^{6}$-BG (1.7-fold), $S^{6}$-CMG (1.8fold), and $O^{6}$-CMG (2.0-fold)], as shown in Figure 4B. Again, ANOVA detected a significant interaction between cisplatin dose and treatment group $(\mathrm{p}<0.0001)$ in the apoptosis experiment as well.

CDK2 inhibition and cell cycle perturbation. In an effort to elucidate whether cell cycle perturbation was related to the degree of enhancement of cisplatin-induced cytotoxicity, the 
percentage of cells in G1, S, and G2/M phase was analyzed following treatment with the four most potent CDK2 inhibitors (Figure 5). In the absence of cisplatin, there is no difference between the cells that were treated with guanine derivative $(10 \mu \mathrm{M})$ and the vehicle-treated cells in $\mathrm{G} 1, \mathrm{~S}$, or G2/M phase distributions. However, in the presence of cisplatin, cells treated with $10 \mu \mathrm{M} S^{6}-\mathrm{CMG}$ and $O^{6}-\mathrm{CMG}$ demonstrated a statistically significant decrease in the number of cells in $\mathrm{S}$ phase at $\mathrm{t}=16 \mathrm{~h}$ following treatment, as determined using the two-tailed Student's t test $(\mathrm{p}<0.001)$. Using the same statistical test, there was also a statistically significant increase in the percentage of cells in $\mathrm{G} 2 / \mathrm{M}$ with all modulators in the presence of cisplatin compared to control cells $(\mathrm{p}<0.05)($ Figure 5).

Effect of modulators on platination of DNA following treatment with cisplatin. To ascertain whether the increased cytotoxicity and apoptosis induced by the guanine derivatives was related to higher levels of DNA platination damage, atomic absorption spectroscopy was employed. DNA isolated from cisplatin-treated SQ20b cells had higher levels of platination at 0,24 , and 48 h when pretreated with $100 \mu \mathrm{M}$ of guanine derivative compared to cells treated with cisplatin alone (Figure 6). This increase was observed up to $48 \mathrm{~h}$. ANOVA detected a significant effect of treatment $(\mathrm{p}=0.0001)$. There was not a significant increase in the amount of platinum on DNA with guanine derivatives at $10 \mu \mathrm{M}$ (data not shown). DNA platination experiments were also conducted using 9- $\mathrm{CH}_{3}-\mathrm{BG}, 9-\mathrm{CH}_{3}-\mathrm{CMG}$ and $\mathrm{N} 7-\mathrm{BG}$ at $50 \mu \mathrm{M}$ (data not shown). 9- $\mathrm{CH}_{3}-\mathrm{CMG}$ and N7-BG demonstrated no increase in DNA platination, and 9- $\mathrm{CH}_{3}-\mathrm{BG}$ treatment demonstrated slightly significantly higher levels of platination at 0,24 , and $48 \mathrm{~h}$ compared to cisplatin alone $(\mathrm{p}<0.05)$. 
Effect of combination of TSA with $O^{6}-B G$ and cisplatin. Previously, $O^{6}-\mathrm{BG}$ was shown to inhibit CDK2/cyclinA3 (Arris et al., 2000) and to enhance the sensitivity of head and neck cancer cells to cisplatin (Fishel et al., 2003). We therefore sought to determine whether further enhancement would occur in the presence of TSA, an indirect cell cycle inhibitor. In SQ20b cells, TSA alone or $O^{6}$-BG alone decreased the $\mathrm{ED}_{10}$ of cisplatin 1.4-fold and 1.9-fold, respectively (Figure 7). However, the combination of TSA $(25 \mathrm{ng} / \mathrm{mL})$ and $O^{6}-\mathrm{BG}(50 \mu \mathrm{M})$ resulted in a more dramatic enhancement of cisplatin-induced cytotoxicity, decreasing the $\mathrm{ED}_{10}$ of cisplatin 2.5-fold compared to cisplatin alone (Figure 7). ANOVA demonstrated that cell survival was different across the four treatment groups $(\mathrm{p}<0.0001)$. The combination of both modulators, $O^{6}-\mathrm{BG}$ plus TSA, on cisplatin cytotoxicity was additive compared to either modulator plus cisplatin based on the interaction terms in the ANOVA models for increasing cisplatin doses in the presence of TSA and $O^{6}$-BG not being statistically significant.

\section{DISCUSSION}

Cisplatin and other platinum derivatives are used widely against several types of human cancers including testicular cancer, metastatic lung cancer, relapsed lymphomas, head and neck cancer, and gynecologic cancers, and the goal of this research is to improve platinating agent efficacy. Previously, we had shown that $O^{6}$-BG, a potent $O^{6}$-alkylguanineDNA alkyltransferase (AGT) inactivator and a weak CDK2 inhibitor, enhanced cisplatininduced cytotoxicity, apoptosis, and DNA platination. In this report, we extend these findings to evaluate a group of similarly structured guanine derivatives for their ability to enhance cisplatin-induced cytotoxicity. To ascertain the role of CDK2 inhibition, we compared more 
and less potent CDK2 inhibitors with the extent of cisplatin-enhanced cytotoxicity and apoptosis. Our data suggests that cell cycle perturbation resulting from CDK2 inhibition is likely the mechanism of the enhancement of cisplatin-induced cytotoxicity. We also tested the combination of both a direct $\left(O^{6}-\mathrm{BG}\right)$, and an indirect cell cycle inhibitor (TSA), which resulted in a dramatic, albeit additive, effect on cisplatin-induced cytotoxicity. This implies that $O^{6}$-BG and TSA are enhancing cisplatin-induced cytotoxicity through different mechanisms.

$O^{6}$-BG-mediated enhancement of cisplatin- and carboplatin-induced cytotoxicity is independent of AGT status (Fishel et al., 2003), nucleotide excision repair (NER) capacity or glutathione (GSH) concentrations (Fishel et al., 2004). Similar to many other drugs developed with a known mechanism, on closer examination additional mechanisms of action and applications of $O^{6}$-BG are becoming evident. Evidence in favor of CDK2 as a mechanism of cisplatin enhanced cytotoxicity is as follows: 1) the more potent CDK inhibitors proved to be the more potent modulators of cisplatin-induced cytotoxicity; 2) all 3 poor inhibitors of CDK2 inhibitors, 9- $\mathrm{CH}_{3}-\mathrm{CMG}$, 9- $\mathrm{CH}_{3}-\mathrm{BG}$ and $\mathrm{N7}-\mathrm{BG}$, were less or ineffective at enhancing cisplatin-induced cytotoxicity; 3) the observed enhancement of cisplatin-induced cytotoxicity by $O^{6}$-BG is dependent of the sequence of administration, with a dramatic increase in cisplatin-induced cytotoxicity, apoptosis and DNA platination observed only in cells incubated with $O^{6}$-BG prior to and during cisplatin exposure (Fishel et al., 2004). Sequence dependency is consistent with many cell cycle inhibitors (Shah and Schwartz, 2001); and 4) a significant decrease in the percentage of cells in S phase and an increase in cells in G2/M when cisplatin was used in combination with $O^{6}$-CMG and $S^{6}$ - 
CMG was observed. Our findings therefore implicate cell cycle modulation by CDK inhibition as a key event.

CDK2 is overexpressed and oftentimes correlated with prognosis in head and neck cancers (Dong et al., 2001; Mihara et al., 2001; Shintani et al., 2002), ovarian cancer (Barboule et al., 1998; Marone et al., 1998; Sui et al., 2001), and melanoma (Tang et al., 1999) providing a rationale for exploring cell cycle modulation of cisplatin-induced cytotoxicity. CDK2/cyclin $\mathrm{E}$ is important in the G1 to $\mathrm{S}$ phase transition, and CDK2/cyclin $\mathrm{A}$ is important during $\mathrm{S}$ phase making it a reasonable target for cancer therapy especially in cancers where expression is elevated (reviewed in (Wadler, 2001)). Typically, when cells are arrested at the G1/S or G2/M checkpoints following DNA damage, and not allowed to progress to $\mathrm{S}$ phase or mitosis, respectively, it is advantageous to the cell as it may avoid replication on a damaged template or the transmission of damaged genetic material to the daughter cells. Higher doses of CDK inhibitors tend to accumulate cells in G2/M while lower doses block cells at G1 (Meijer et al., 1999), and these effects could explain the decrease of cells in S phase observed in the current study with two of the more potent CDK inhibitors, $O^{6}-\mathrm{CMG}$ and $S^{6}-\mathrm{CMG}$. Perturbation of the cell cycle during treatment with cisplatin could cause changes in the cellular response to the drug relating to the formation, detection and processing of platinum lesions, or more generally in the expression of cell cycle-regulated genes such as histones. Whatever the mechanism operating, the effect of CDK inhibition on cisplatin-induced cytotoxicity apparently overrides any reduction in cellular sensitivity that could, in theory, arise as a result of the inhibition of cell cycle progression by the CDK inhibitor.

The mechanism of action of TSA is believed to be through inhibition of histone deacetylases (HDAC) leading to an alteration of chromatin acetylation and structure 
(Yoshida et al., 1990). Modest enhancement of cisplatin cytotoxicity by TSA has been observed in MCF-7 breast cancer cells, and this enhancement was more dramatic when TSA treatment preceded cisplatin exposure (Kim et al., 2003). In the current study, the potentiation of cisplatin by TSA was confirmed and greater potentiation of cisplatin-induced cytotoxicity achieved with the combination of $O^{6}-\mathrm{BG}$ and TSA. There might therefore be value in considering this three drug combination clinically.

In contrast to other cell cycle inhibitors, $O^{6}$-BG has shown only limited side effects in Phase II/III clinical trials (Friedman et al., 1998; Spiro et al., 1999; Friedman et al., 2000; Schilsky et al., 2000). However, at the doses used to modulate AGT activity, $O^{6}$-BG may lack potency as a cell cycle modulator. The most potent modulator of cisplatin activity and the most potent CDK inhibitor of the guanine derivatives identified in the current study, $O^{6}$ CMG, enhanced cisplatin at a 10 -fold lower concentration than $O^{6}-\mathrm{BG}$, and hence $O^{6}-\mathrm{CMG}$ may have clinical potential as a cisplatin modulator. In addition, we are currently delving deeper into the mechanism of modulation of cisplatin-induced cytotoxicity with the guanine derivatives along with studies of the structure-activity relationship in efforts to design a clinically feasible modulator of platinating agents. 


\section{REFERENCES}

Akiyama T, Yoshida T, Tsujita T, Shimizu M, Mizukami T, Okabe M and Akinaga S (1997) G1 phase accumulation induced by $\mathrm{UCN}-01$ is associated with dephosphorylation of $\mathrm{Rb}$ and CDK2 proteins as well as induction of CDK inhibitor p21/Cip1/WAF1/Sdi1 in p53mutated human epidermoid carcinoma A431 cells. Cancer Res 57:1495-1501.

Arris CE, Bleasdale C, Calvert AH, Curtin NJ, Dalby C, Golding BT, Griffin RJ, Lunn JM, Major GN and Newell DR (1994) Probing the active site and mechanism of action of $\mathrm{O}^{6}$ methylguanine-DNA methyltransferase with substrate analogues $\left(\mathrm{O}^{6}\right.$-substituted guanines). Anticancer Drug Des 9:401-408.

Arris CE, Boyle FT, Calvert AH, Curtin NJ, Endicott JA, Garman EF, Gibson AE, Golding BT, Grant S, Griffin RJ, Jewsbury P, Johnson LN, Lawrie AM, Newell DR, Noble ME, Sausville EA, Schultz R and Yu W (2000) Identification of novel purine and pyrimidine cyclin-dependent kinase inhibitors with distinct molecular interactions and tumor cell growth inhibition profiles. J Med Chem 43:2797-2804.

Barboule N, Baldin V, S JO, Vidal S and Valette A (1998) Increased level of p21 in human ovarian tumors is associated with increased expression of cdk2, cyclin A and PCNA. Int J Cancer 76:891-896.

Bertrand R, Solary E, O'Connor P, Kohn KW and Pommier Y (1994) Induction of a common pathway of apoptosis by staurosporine. Exp Cell Res 211:314-321.

Carlson BA, Dubay MM, Sausville EA, Brizuela L and Worland PJ (1996) Flavopiridol induces G1 arrest with inhibition of cyclin-dependent kinase (CDK) 2 and CDK4 in human breast carcinoma cells. Cancer Res 56:2973-2978. 
Chae MY, McDougall MG, Dolan ME, Swenn K, Pegg AE and Moschel RC (1994) Substituted $\mathrm{O}^{6}$-benzylguanine derivatives and their inactivation of human $O^{6}$-alkylguanine-DNA alkyltransferase. J Med Chem 37:342-347.

Davies TG, Bentley J, Arris CE, Boyle FT, Curtin NJ, Endicott JA, Gibson AE, Golding BT, Griffin RJ, Hardcastle IR, Jewsbury P, Johnson LN, Mesguiche V, Newell DR, Noble ME, Tucker JA, Wang L and Whitfield HJ (2002) Structure-based design of a potent purine-based cyclin-dependent kinase inhibitor. Nat Struct Biol 9:745-749.

De Azevedo WF, Leclerc S, Meijer L, Havlicek L, Strnad M and Kim SH (1997) Inhibition of cyclin-dependent kinases by purine analogues: crystal structure of human cdk2 complexed with roscovitine. Eur J Biochem 243:518-526.

Dolan ME, Moschel RC and Pegg AE (1990) Depletion of mammalian $O^{6}$-alkylguanine-DNA alkyltransferase activity by $O^{6}$-benzylguanine provides a means to evaluate the role of this protein in protection against carcinogenic and therapeutic alkylating agents. Proc Natl Acad Sci U S A 87:5368-5372.

Dong Y, Sui L, Tai Y, Sugimoto K and Tokuda M (2001) The overexpression of cyclindependent kinase (CDK) 2 in laryngeal squamous cell carcinomas. Anticancer Res 21:103-108.

Erkmen K, Egorin MJ, Reyno LM, Morgan R, Jr. and Doroshow JH (1995) Effects of storage on the binding of carboplatin to plasma proteins. Cancer Chemother Pharmacol 35:254-256.

Fishel ML, Delaney SM, Durtan LJ, Hansen RJ, Zuhowski EG, Moschel RC, Egorin MJ and Dolan ME (2003) Enhancement of platinum-induced cytotoxicity by $O^{6}$-benzylguanine. Molecular Cancer Therapeutics 2:633-640. 
Fishel ML, Gamcsik MP, Delaney SM, Zuhowski EG, Maher VM, Karrison T, Moschel RC, Egorin MJ and Dolan ME (2004) Role of GSH and NER in modulation of cisplatin activity with $O^{6}$-benzylguanine. Cancer Chemother Pcol In press.

Friedman HS, Kokkinakis DM, Pluda J, Friedman AH, Cokgor I, Haglund MM, Ashley DM, Rich J, Dolan ME, Pegg AE, Moschel RC, McLendon RE, Kerby T, Herndon JE, Bigner DD and Schold SC, Jr. (1998) Phase I trial of $O^{6}$-benzylguanine for patients undergoing surgery for malignant glioma. J Clin Oncol 16:3570-3575.

Friedman HS, Pluda J, Quinn JA, Ewesuedo RB, Long L, Friedman AH, Cokgor I, Colvin OM, Haglund MM, Ashley DM, Rich JN, Sampson J, Pegg AE, Moschel RC, McLendon RE, Provenzale JM, Stewart ES, Tourt-Uhlig S, Garcia-Turner AM, Herndon JE, 2nd, Bigner DD and Dolan ME (2000) Phase I trial of carmustine plus $O^{6}$-benzylguanine for patients with recurrent or progressive malignant glioma. J Clin Oncol 18:3522-3528.

Gibson AE, Arris CE, Bentley J, T. BF, Curtin NJ, Davies TG, Endicott JA, Golding BT, Grant S, Griffin RJ, Jewsbury P, Johnson LN, Mesguiche V, Newell DR, Noble ME, Tucker JA and Whitfield HJ (2002) Probing the ATP ribose-binding domain of cyclin-dependent kinases 1 and 2 with $\mathrm{O}(6)$-substituted guanine derivatives. J. of Med. Chem. 45:33813393.

Grant S and Roberts JD (2003) The use of cyclin-dependent kinase inhibitors alone or in combination with established cytotoxic drugs in cancer chemotherapy. Drug Resist Updat 6:15-26.

Kim MS, Blake M, Baek JH, Kohlhagen G, Pommier Y and Carrier F (2003) Inhibition of histone deacetylase increases cytotoxicity to anticancer drugs targeting DNA. Cancer Res 63:7291-7300. 
Knockaert M, Greengard P and Meijer L (2002) Pharmacological inhibitors of cyclin-dependent kinases. Trends Pharmacol Sci 23:417-425.

Lembicz NK, Grant S, Clegg W, Griffin RJ, Heath SL and Golding BT (1997) Facilitation of displacements at the 6-position of purines by the use of 1,4-diazabicyclo[2,2,2]octane as leaving group. J. Chem. Soc., Perkin Trans. 1 3:185-186.

Marone M, Scambia G, Giannitelli C, Ferrandina G, Masciullo V, Bellacosa A, Benedetti-Panici P and Mancuso S (1998) Analysis of cyclin E and CDK2 in ovarian cancer: gene amplification and RNA overexpression. Int J Cancer 75:34-39.

Meijer L, Leclerc S and Leost M (1999) Properties and potential-applications of chemical inhibitors of cyclin-dependent kinases. Pharmacol Ther 82:279-284.

Mihara M, Shintani S, Nakahara Y, Kiyota A, Ueyama Y, Matsumura T and Wong DT (2001) Overexpression of CDK2 is a prognostic indicator of oral cancer progression. Jpn J Cancer Res 92:352-360.

Mizuno K, Noda K, Ueda Y, Hanaki H, Saido TC, Ikuta T, Kuroki T, Tamaoki T, Hirai S, Osada S and et al. (1995) UCN-01, an anti-tumor drug, is a selective inhibitor of the conventional PKC subfamily. FEBS Lett 359:259-261.

Moschel RC, McDougall MG, Dolan ME, Stine L and Pegg AE (1992) Structural features of substituted purine derivatives compatible with depletion of human $O^{6}$-alkylguanine-DNA alkyltransferase. J Med Chem 35:4486-4491.

Parker BW, Kaur G, Nieves-Neira W, Taimi M, Kohlhagen G, Shimizu T, Losiewicz MD, Pommier Y, Sausville EA and Senderowicz AM (1998) Early induction of apoptosis in hematopoietic cell lines after exposure to flavopiridol. Blood 91:458-465. 
Ruetz S, Fabbro D, Zimmermann J, Meyer T and Gray N (2003) Chemical and biological profile of dual Cdk1 and Cdk2 inhibitors. Curr Med Chem Anti-Canc Agents 3:1-14.

Sausville EA, Arbuck SG, Messmann R, Headlee D, Bauer KS, Lush RM, Murgo A, Figg WD, Lahusen T, Jaken S, Jing X, Roberge M, Fuse E, Kuwabara T and Senderowicz AM (2001) Phase I trial of 72-hour continuous infusion UCN-01 in patients with refractory neoplasms. J Clin Oncol 19:2319-2333.

Schilsky RL, Dolan ME, Bertucci D, Ewesuedo RB, Vogelzang NJ, Mani S, Wilson LR and Ratain MJ (2000) Phase I clinical and pharmacological study of $O^{6}$-benzylguanine followed by carmustine in patients with advanced cancer. Clin Cancer Res 6:3025-3031. Schulze-Gahmen U, Brandsen J, Jones HD, Morgan DO, Meijer L, Vesely J and Kim SH (1995) Multiple modes of ligand recognition: crystal structures of cyclin-dependent protein kinase 2 in complex with ATP and two inhibitors, olomoucine and isopentenyladenine. Proteins 22:378-391.

Senderowicz AM (2003a) Novel direct and indirect cyclin-dependent kinase modulators for the prevention and treatment of human neoplasms. Cancer Chemother Pharmacol 52 Suppl 1:S61-73.

Senderowicz AM (2003b) Small-molecule cyclin-dependent kinase modulators. Oncogene 22:6609-6620.

Shah MA and Schwartz GK (2001) Cell cycle-mediated drug resistance: an emerging concept in cancer therapy. Clin Cancer Res 7:2168-2181.

Shintani S, Mihara M, Nakahara Y, Kiyota A, Ueyama Y, Matsumura T and Wong DT (2002) Expression of cell cycle control proteins in normal epithelium, premalignant and malignant lesions of oral cavity. Oral Oncol 38:235-243. 
Spiro TP, Gerson SL, Liu L, Majka S, Haaga J, Hoppel CL, Ingalls ST, Pluda JM and Willson JK (1999) $O^{6}$-benzylguanine: a clinical trial establishing the biochemical modulatory dose in tumor tissue for alkyltransferase-directed DNA repair. Cancer Res 59:2402-2410.

Sui L, Dong Y, Ohno M, Sugimoto K, Tai Y, Hando T and Tokuda M (2001) Implication of malignancy and prognosis of p27(kip1), Cyclin E, and Cdk2 expression in epithelial ovarian tumors. Gynecol Oncol 83:56-63.

Tang L, Li G, Tron VA, Trotter MJ and Ho VC (1999) Expression of cell cycle regulators in human cutaneous malignant melanoma. Melanoma Res 9:148-154.

Toogood PL (2001) Cyclin-dependent kinase inhibitors for treating cancer. Med Res Rev 21:487498.

Vermeulen K, Van Bockstaele DR and Berneman ZN (2003) The cell cycle: a review of regulation, deregulation and therapeutic targets in cancer. Cell Prolif 36:131-149.

Wadler S (2001) Perspectives for cancer therapies with cdk2 inhibitors. Drug Resist Updat 4:347-367.

Yoshida M, Kijima M, Akita M and Beppu T (1990) Potent and specific inhibition of mammalian histone deacetylase both in vivo and in vitro by trichostatin A. J Biol Chem 265:17174-17179. 


\section{Footnotes.}

* Supported, in part, by NIH Grant CA81485. This work was supported in part by grants from Cancer Research UK.

To whom requests for reprints should be addressed: M. Eileen Dolan, 5841 S. Maryland Ave., Box MC2115, University of Chicago, Chicago, IL 60637. Phone: (773) 702-4441;

Fax: (773) 702-0963; E-mail: edolan@ medicine.bsd.uchicago.edu

Dr. Dolan is co-inventor of $O^{6}$-benzylguanine, a compound that has been licensed to Access Oncology, Inc. 


\section{Figure Legends}

Figure 1. Chemical structures of guanine derivatives used in combination with cisplatin.

Figure 2. Effect of guanine derivatives on cisplatin cytotoxicity in SQ20b cells. A. Colony formation assay of SQ20b cells treated with guanine derivative at $10 \mu \mathrm{M}$ for $2 \mathrm{~h}$ prior and during the $2 \mathrm{~h}$ cisplatin exposure. B. Colony formation assay of SQ20b cells treated with guanine derivative at $100 \mu \mathrm{M}$ for $2 \mathrm{~h}$ prior and during cisplatin exposure. Percentage survival is calculated as described in Materials and Methods. Each data point represents the mean $+/-\mathrm{SE}$ from at least 2 separate experiments with each experiment representing 6 replicate dishes per treatment group. C. SQ20b cells treated with guanine derivative at $10 \mu \mathrm{M}$ for $2 \mathrm{~h}$ prior and during cisplatin exposure $(2 \mathrm{~h})$ and assayed for apoptosis $96 \mathrm{~h}$ following cisplatin treatment. Shown here is a representative experiment of the assay performed in triplicate. $S^{6}$-CMG and $O^{6}$ CMG treatment in combination with cisplatin induced significantly greater levels of apoptosis than cisplatin alone $(\mathrm{p}<0.01)$.

Figure 3. Effect of guanine derivatives that are not CDK inhibitors on cisplatin cytotoxicity. Colony formation assay of SQ20b cells treated with guanine derivative at $50 \mu \mathrm{M}$ for $2 \mathrm{~h}$ prior and during cisplatin exposure (2h). Percentage survival is calculated as described in Materials and Methods. Each data point represents the mean $+/-$ SE from at least 5 separate experiments with each experiment representing 6 replicate dishes per treatment group. Based on subsequent pairwise comparisons of the various treatments versus cisplatin alone, the effect of $9-\mathrm{CH}_{3}-\mathrm{BG}$ and 9- $\mathrm{CH}_{3}-\mathrm{CMG}$ plus cisplatin on cell survival compared to cisplatin alone depended on the cisplatin dose $(* \mathrm{p}<0.05)$. The cytotoxic effects of N7-BG plus cisplatin were not significantly 
different from cisplatin alone $(\mathrm{p}=0.21)$. Inset: $\mathrm{SQ} 20 \mathrm{~b}$ cells treated with $50 \mu \mathrm{M}$ guanine derivative for $2 \mathrm{~h}$ prior to and during $2 \mathrm{~h}$ cisplatin exposure and assayed for apoptosis $96 \mathrm{~h}$ later. Each column represents the mean $+/-\mathrm{SE}$ from at least 4 separate experiments.

Figure 4. Effect of guanine derivatives on cisplatin cytotoxicity in SCC61 cells. A. Colony formation assay of SCC61 cells treated with guanine derivative at $100 \mu \mathrm{M}$ for $2 \mathrm{~h}$ prior and during the $2 \mathrm{~h}$ cisplatin exposure. Percentage survival is calculated as described in Materials and Methods. Each data point represents the mean $+/-$ SE from at least 3 separate experiments with each experiment representing 6 replicate dishes per treatment group. Based on pairwise comparisons, all modulators in combination with cisplatin treatment were statistically significant compared to cisplatin alone (** $S^{6}$-CMG, $O^{6}$-CMG, $\leq \leq 0.01$ ), with $O^{6}$-BG and $S^{6}$-BG being moderately significant.(* $\mathrm{p} \leq 0.05)$. B. SCC61 cells treated with guanine derivative at $100 \mu \mathrm{M}$ for $2 \mathrm{~h}$ prior and during cisplatin exposure $(2 \mathrm{~h})$ and assayed for apoptosis $96 \mathrm{~h}$ after cisplatin treatment. Shown here is the average of 3 separate experiments ( $\pm \mathrm{SE}$ ). $S^{6}-\mathrm{BG}, O^{6}-\mathrm{BG}, S^{6}-\mathrm{CMG}$, and $O^{6}$-CMG treatment in combination with cisplatin induced significantly greater levels of apoptosis than cisplatin treatment alone $(\mathrm{p}<0.0001, \mathrm{p}<0.05, \mathrm{p}<0.0001$, and $\mathrm{p}<0.00001$, respectively).

Figure 5. Effect of guanine derivatives on cell cycle phase distribution. Cell cycle distribution was determined using PI staining of SQ20b cells treated with guanine derivatives $(10 \mu \mathrm{M}) 2 \mathrm{~h}$ prior to and during cisplatin exposure $(50 \mu \mathrm{M}, 2 \mathrm{~h})$. Cells were collected and fixed $16 \mathrm{~h}$ after cisplatin treatment. Each data point represents the mean $+/-\mathrm{SE}$ from 3 separate experiments. (* 
$\mathrm{p}<0.05$, compared to cisplatin treatment alone; $* * * \mathrm{p}<0.001$, compared to cisplatin treatment alone; \# $\mathrm{p}<0.05$, compared to cells not treated with cisplatin.)

Figure 6. Effect of guanine derivatives on DNA adduct levels following cisplatin treatment. Platination on DNA of SQ20b cells treated $100 \mu \mathrm{M}$ guanine derivative plus cisplatin $(50 \mu \mathrm{M})$ or cisplatin alone. Cells were collected 0,24 , and $48 \mathrm{~h}$ after cisplatin treatment. Total DNA platinum adducts were measured using atomic absorption spectrometry as described in Materials and Methods. Pt levels are expressed relative to cisplatin treatment alone using the average from at least 3 separate experiments. The effect of treatment averaged across the 3 time points for $S^{6}$ BG, $S^{6}-\mathrm{CMG}$, and $O^{6}-\mathrm{CMG}$ treatment in combination with cisplatin was significantly greater than cisplatin treatment alone $(\mathrm{p} \leq 0.001)$.

Figure 7. Effect of $O^{6}-\mathrm{BG}$ and TSA treatment on cisplatin cytotoxicity. The following four treatment groups were used: cisplatin alone (closed squares), TSA $(25 \mathrm{ng} / \mathrm{mL})$ plus cisplatin (open circles), $O^{6}$-BG $(50 \mu \mathrm{M})$ plus cisplatin (closed triangles), and TSA plus $O^{6}$-BG plus cisplatin (crossed squares). TSA treatment was $24 \mathrm{~h}$ prior to $O^{6}-\mathrm{BG}$ and/or cisplatin treatment. $O^{6}$-BG treatment schedule was $2 \mathrm{~h}$ prior to and during the $2 \mathrm{~h}$ cisplatin exposure. Cytotoxicity was measured as colony forming ability 10-12 days after treatment. Each data point represents the mean + /- SE from at least 3 separate experiments with each experiment representing 6 replicate dishes per treatment group. Based on pairwise comparisons of the combined treatments versus cisplatin alone, $O^{6}-\mathrm{BG}+$ cisplatin and $O^{6}-\mathrm{BG}$ plus TSA plus cisplatin resulted in significantly greater enhancement of cytotoxicity compared to cisplatin alone ( $* * * \mathrm{p} \leq 0.0001)$. TSA treatment 
alone had significantly greater cytotoxicity than vehicle-treated cells, and this difference remained fairly constant across the cisplatin doses $(* \mathrm{p}<0.05)$. 
Table 1. Inhibition of CDK2 by guanine derivatives.

\begin{tabular}{|l|c|}
\hline Compound & IC50 $(\mu \mathrm{M})$ CDK2/cyclinA3 \\
\hline$O^{6}-\mathrm{CMG}$ & $17 \pm 2$ (Arris et al., 2000) \\
\hline$S^{6}-\mathrm{CMG}$ & $26 \pm 7$ \\
\hline $0^{6}-\mathrm{BG}$ & $35 \pm 6$ (Gibson et al., 2002) \\
\hline$S^{6}-\mathrm{BG}$ & $92 \pm 12$ \\
\hline $9-\mathrm{CH}_{3}-\mathrm{BG}$ & $>100$ \\
\hline $9-\mathrm{CH}_{3}-\mathrm{CMG}$ & $>100$ (Arris et al., 2000) \\
\hline $\mathrm{N} 7-\mathrm{BG}$ & $>100$ \\
\hline
\end{tabular}


<smiles>[R1]c1nc(N)nc2c1ncn2[R1]</smiles>
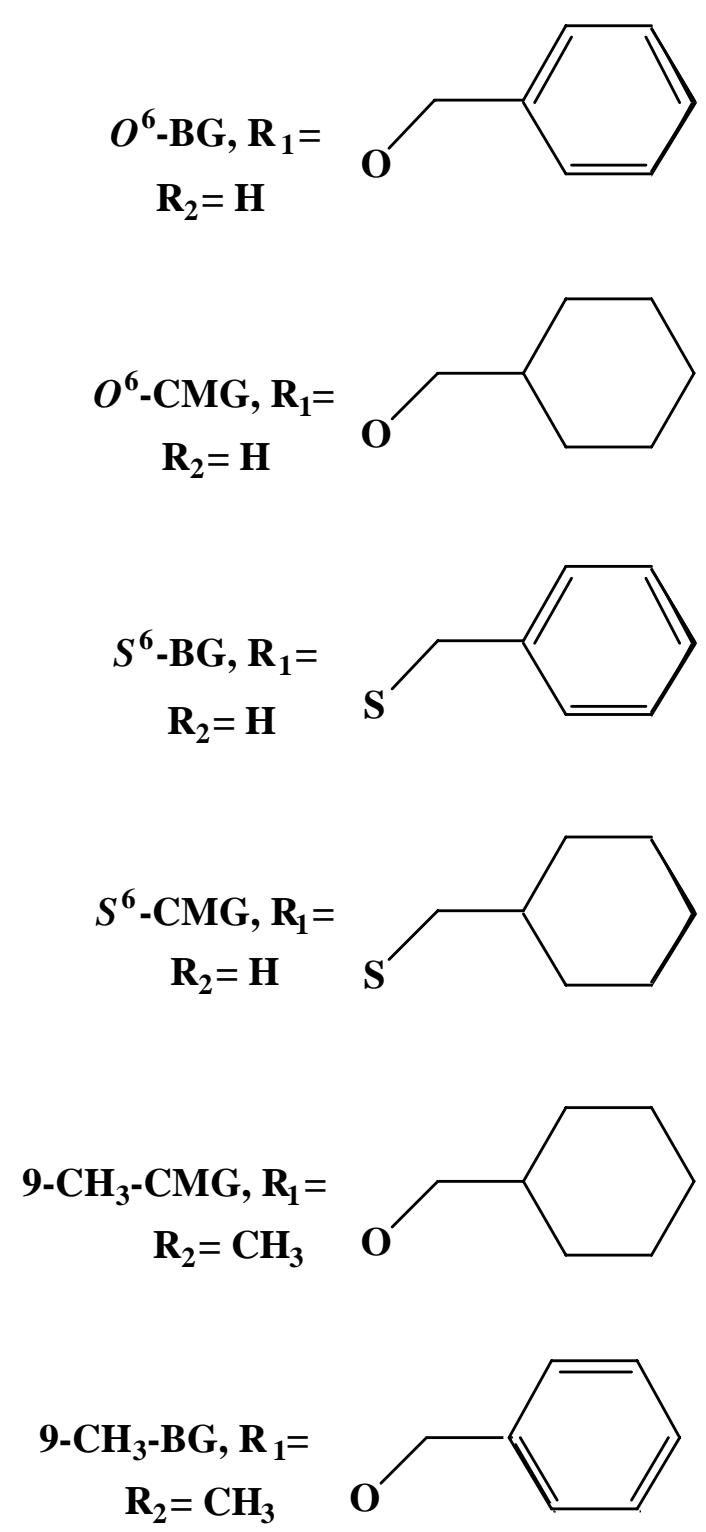

N7-BG

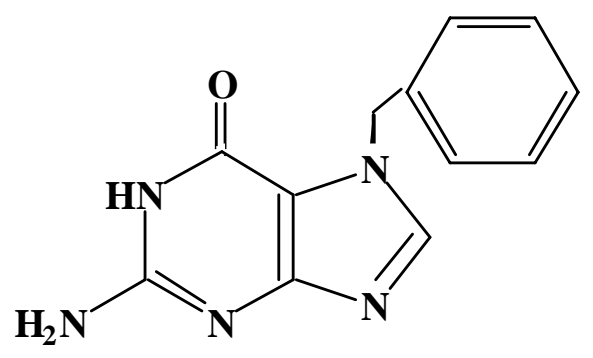



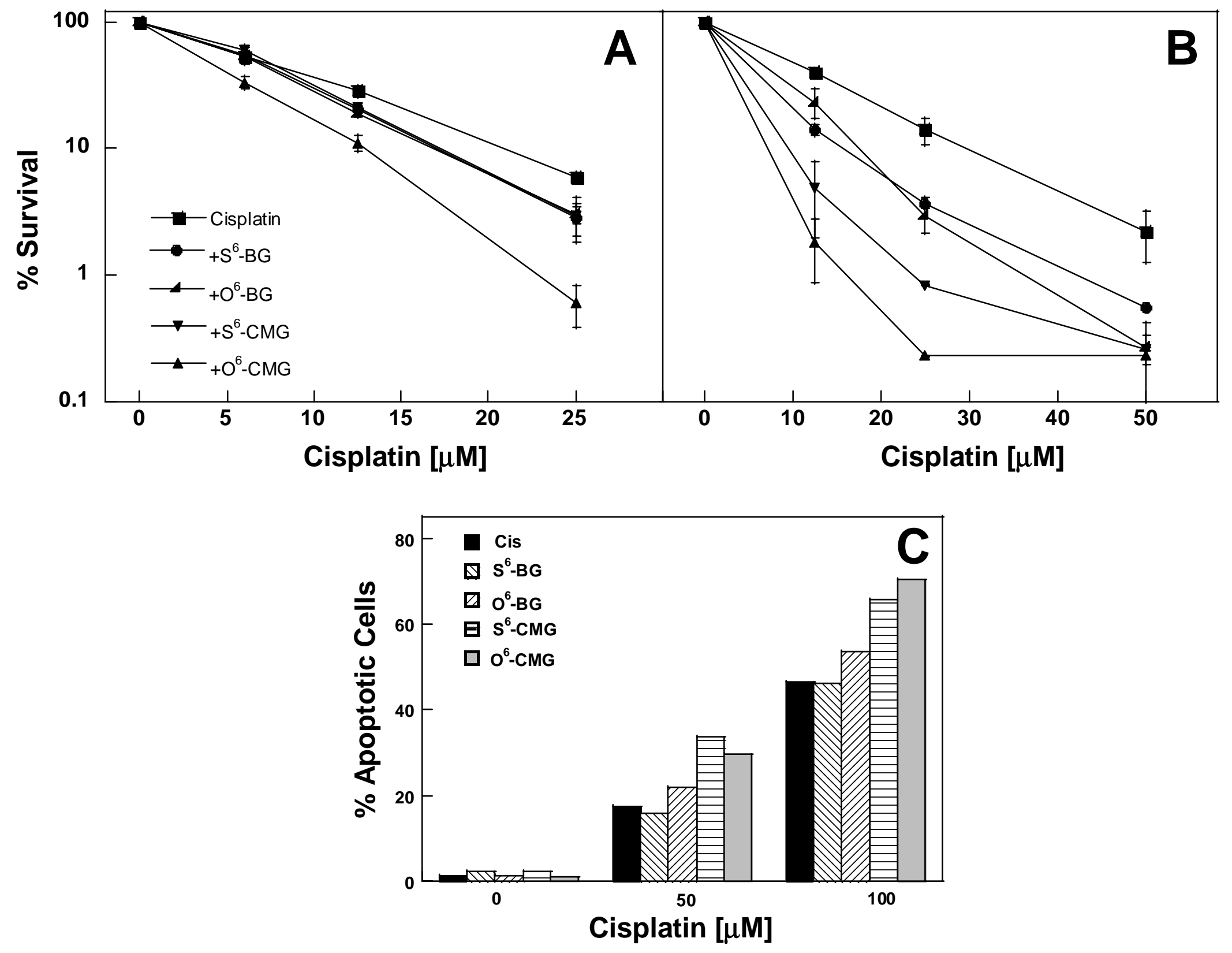


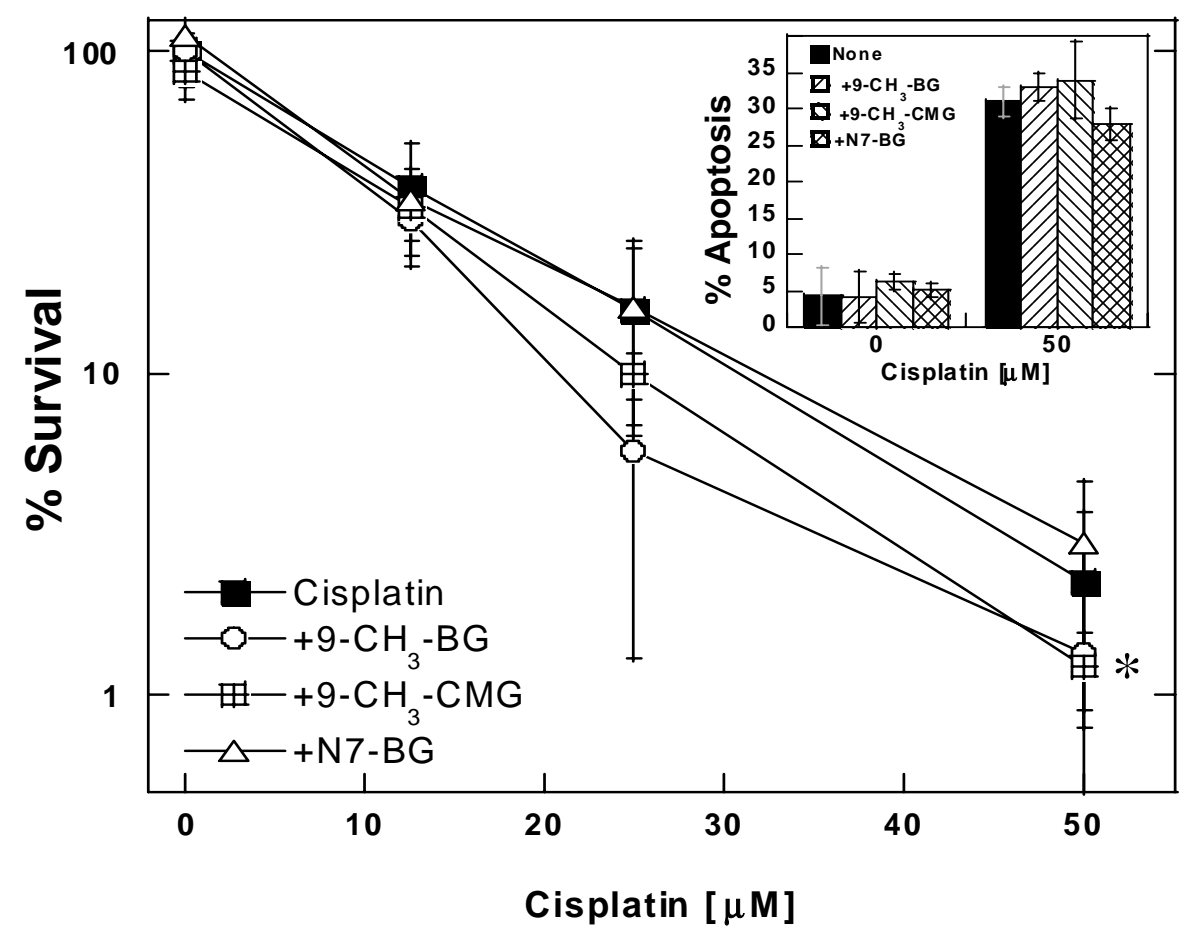



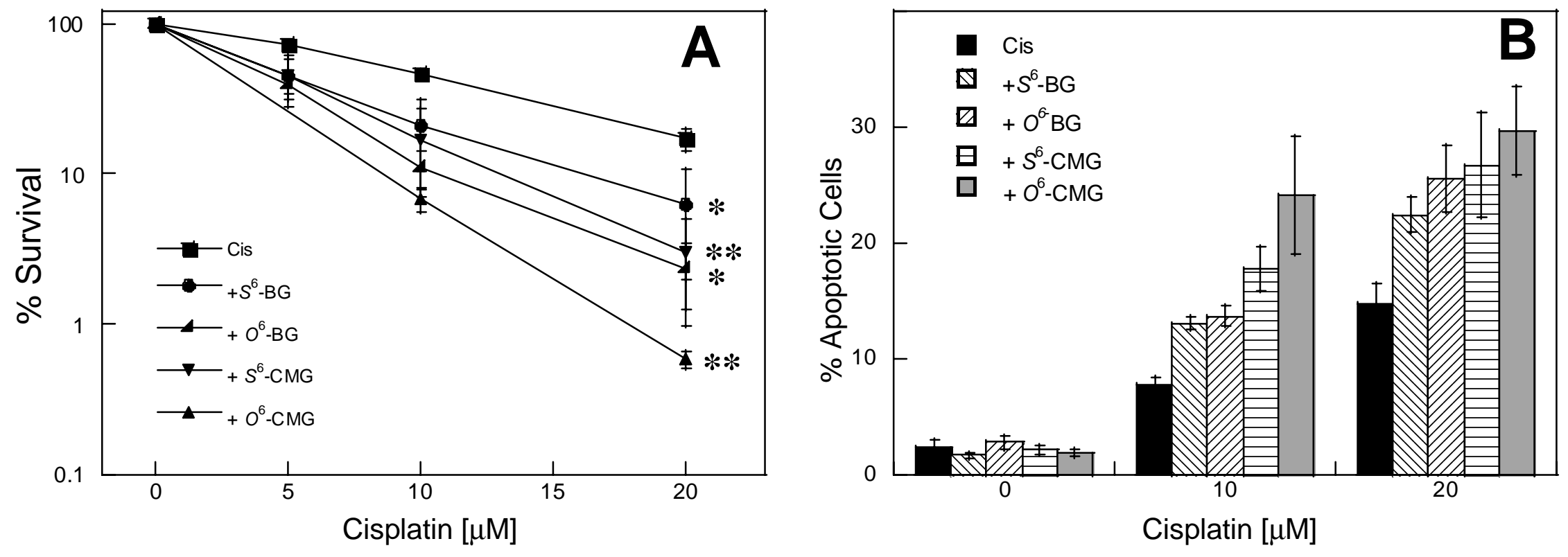


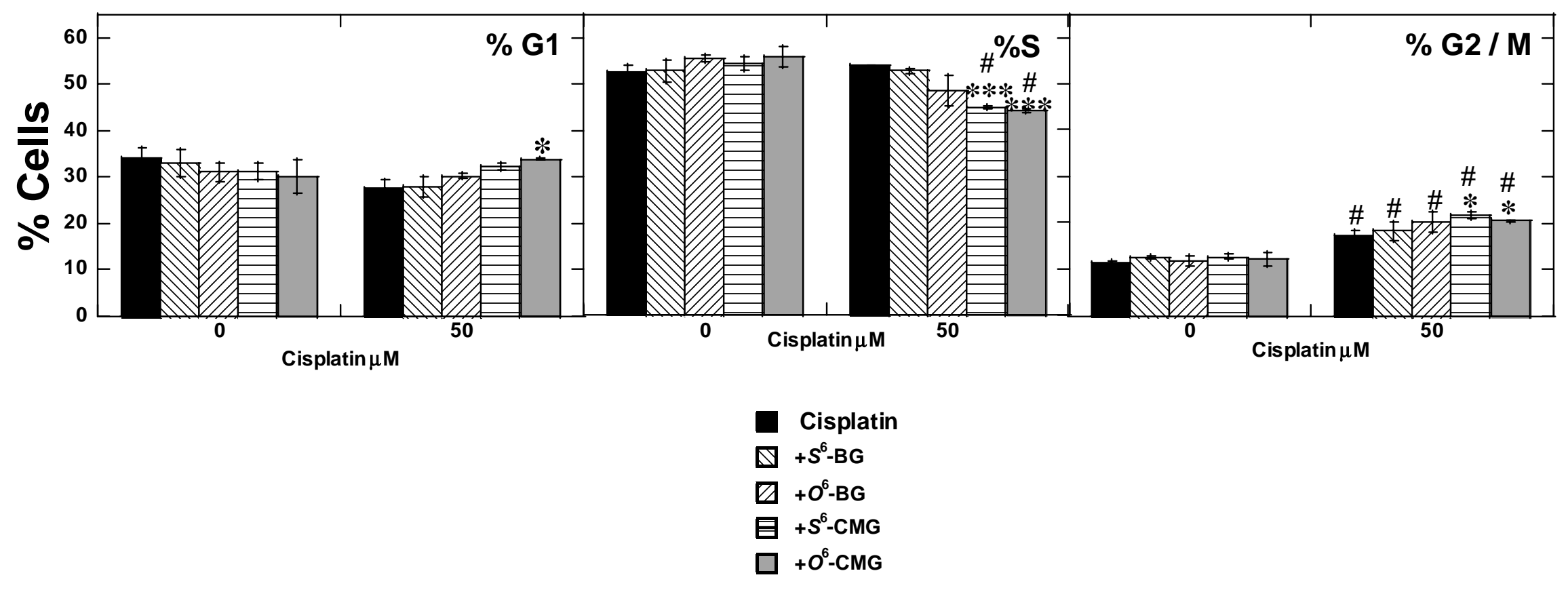




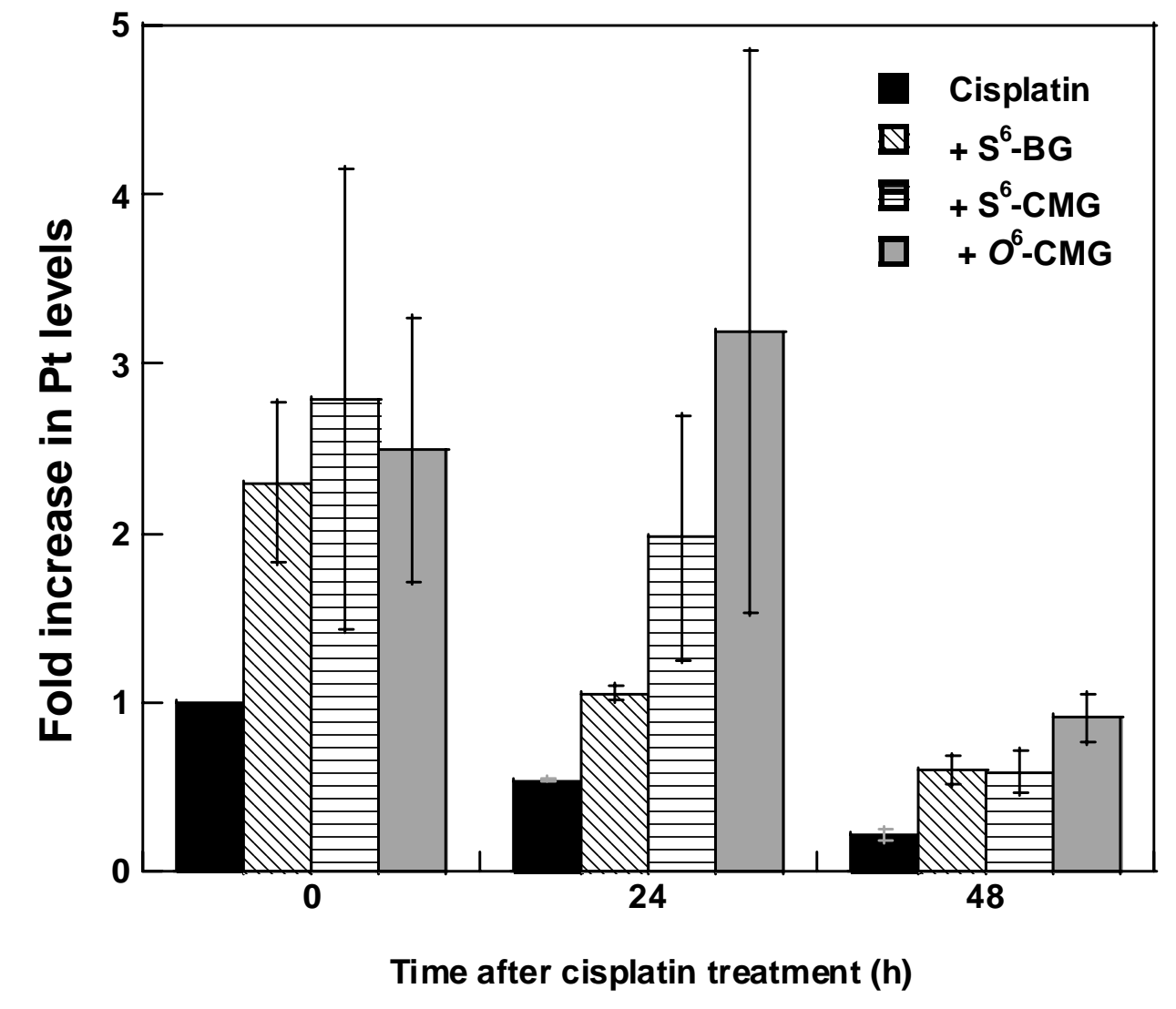

$* \mathrm{p}<0.05$ ${ }^{* \star *} p<0.001$ 


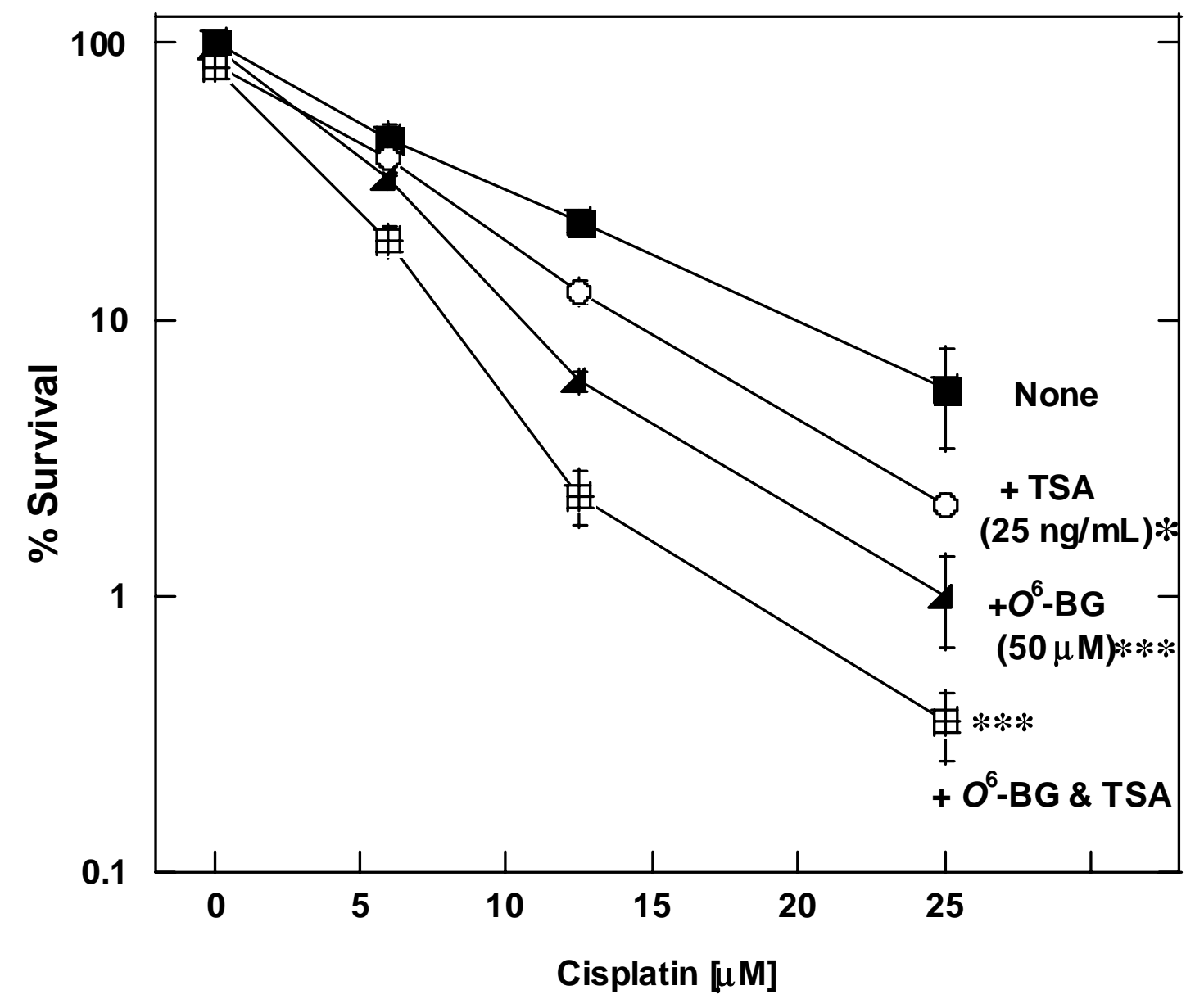

